\title{
The British Society for the History of Science
}

LIKE the discipline which it represents, the British Society for the History of Science has grown considerably since its foundation in 1947 . The object of the Society is to further the discipline in all possible ways, particularly by holding meetings for the reading and discussion of papers, and by publication of relevant material. The Society offers a forum for all who have an interest in the history of science; although it is based in Britain, its membership is international. It welcomes applications for membership from students as well as established scholars, and from non-specialists as well as professional historians of Science.

Membership of the Society, which includes a subscription to The British Journal for the History of Science, is open to all persons approved by the Council of the Society and elected at an ordinary meeting (formalities required by the UK Companies Act). The annual subscription is $\mathcal{E}_{11} 1.00$ (US\$28.00 in the Americas, Canada, and Japan) or, for students, £4.00 (\$i I.00).

Applications for membership should be made on a form which is available from the Society's Administrator at the address below.

Meetings: The Society mounts an ambitious programme of meetings. The pattern is flexible, the only fixture being the three-day summer meeting, held at a different British University or Polytechnic each year. About four other meetings, lasting for between one and three days, are held during the year, sometimes devoted to a clearly-defined theme or an important anniversary, and often arranged in conjunction with other scholarly societies.

The British Journal for the History of Science is the official organ of the Society. All correspondence on the contents of the Fournal should be addressed to the Editor, David Knight, Department of Philosophy, University of Durham, 50 Old Elvet, Durham DH: ${ }_{3} \mathrm{HN}$, England.

Books for review should be sent to the Reviews Editor, Dr John R. Durant, Department of Extra-Mural Studies, University College of Swansea, 6 Uplands Terrace, Swansea SA2 oGU, West Glamorgan, South Wales.

Advertising: Particulars about advertising in the fournal may be obtained from the Society's Administrator.

Orders and back issues: Orders for the fournal and inquiries about back issues should be addressed to the Administrator. Claims for missing copies should be made within six months of publication. The annual subscription for non-members is $f_{1} 12.00$ (\$30.00).

Other publications: BSHS Monograph Series is designed to allow the publication of monographic studies in the history of science quickly and cheaply. All correspondence on the subject of monographs, and any new suggestions for titles, should be sent to the Series Editor, Dr Roger Smith, Department of History, University of Lancaster, Bailrigg, Lancaster LAI ${ }_{4}$ YG, England. Monographs are available to members at a discount of $25 \%$, post-free from the Society's Administrator. Non-members may obtain them through bookshops, or post-free from the Administrator. Now available:

I. Images of the earth: essays in the history of the environmental sciences. Ed. by L. J. Jordanova and R. Porter. 1979. $£ 5.95$ ( $£ 4.40$ to members).

2. The letters of Georges Cuvier: a summary calendar. Ed. by Dorinda Outram. 1980. $£ 3.90$ ( 22.90 to members).

List of theses: Every December, the Society publishes a full list of current theses in history of science in British universities. This is available free to members, and at a small charge to non-members on request to the Administrator. Standing orders are accepted from members or non-members who wish to receive the list regularly.

The Society's Newsletter, an informal publication edited by Dr P. M. D. Collins, to Woodville Gardens, London $W_{5} 2 L G$, appears in January, May and September each year. It is free to members, $f_{3}$ for institutions and non-members.

All the administrative business of the Society is handled by

The Administrator, The British Society for the History of Science, Halfpenny

Furze, Mill Lane, Chalfont St Giles, Bucks HP8 4 NR, England. 
The British Journal for the History of Science

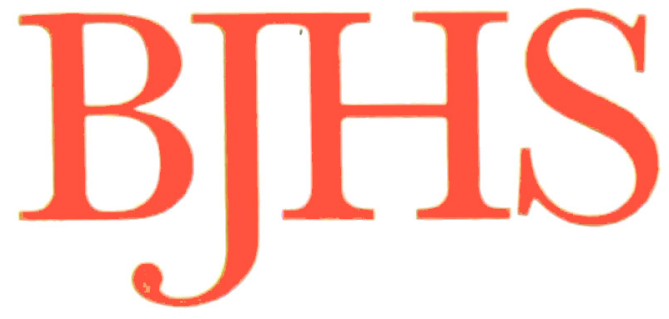

Volume 15 Part I No 49

I Editorial

3 David C. Lindberg: On the Applicability of Mathematics to Nature: Roger Bacon and his predecessors

27 Rhoda Rappaport: Borrowed Words: problems of vocabulary in eighteenth-century geology

45 Mark Ridley: Coadaptation and the Inadequacy of Natural Selection

Essay Review:

69 P. B. Wood: English Scientific Virtuosi

72 Book Reviews

95 Books Received

Published by The British Society for the History of Science Registered Office: Halfpenny Furze, Mill Lane, Chalfont St Giles, Bucks HP8 4 NR

Price: $\ell^{8.00}$ or $\$ 18.00$ including postage (Free to members of the Society)

(C) The British Society for the History of Science 1982 